\title{
Experimental Study of Thermal Performance of One-Ended Evacuated Tubes for Producing Hot Air
}

\author{
Ashish Kumar, Sanjeev Kumar, Utkarsh Nagar, and Avadhesh Yadav \\ Department of Mechanical Engineering, National Institute of Technology, Kurukshetra, Haryana 136119, India \\ Correspondence should be addressed to Ashish Kumar; ashishkumar467@gmail.com
}

Received 20 August 2013; Revised 31 October 2013; Accepted 9 November 2013

Academic Editor: Charles Michael Drain

Copyright (C) 2013 Ashish Kumar et al. This is an open access article distributed under the Creative Commons Attribution License, which permits unrestricted use, distribution, and reproduction in any medium, provided the original work is properly cited.

\begin{abstract}
The thermal performance of an evacuated tube solar air collector is experimentally investigated at different air flow rates. Air is used as a working fluid in experimental setup and tested in Indian climatic conditions. The evacuated tube solar air collector consists of fifteen evacuated tubes and manifold channel. The manifold channel consists of a hollow pipe (square pipe) in centre through which air flows. The temperature difference and efficiency are studied with different air flow rates. The reflectors are used to enhance the performance of evacuated tubes solar air collector. It is observed that in case of reflector evacuated tube solar air collector gives higher outlet temperature and temperature difference and has better thermal performance as compared to the case without reflector. The maximum outlet temperature and temperature difference of air are found to be $97.4^{\circ} \mathrm{C}$ and $74.4^{\circ} \mathrm{C}$ at a flow rate of $6.70 \mathrm{~kg} / \mathrm{hr}$.
\end{abstract}

\section{Introduction}

Nowadays the demand of conventional resources of energy is very high, so these resources are continuously depleting day by day. The development of renewable energy technology is important for the future to balance global energy resources. For many years the evacuated tube has been used to heat the water but it has never been used for the generation of hot air. One-ended glass evacuated tubes are widely used and are widely popular in the world because evacuated tubes have better performance. The performance of flat plate collectors is lower than evacuated tube solar collectors for high temperature operation. The evacuated tube consisting of two concentric tubes is used to heat the fluid flowing inside the inner tube. The outer portion of the inner glass tube is coated with an absorbing material to absorb heat.

A review of the literature suggests that considerable efforts have been made in the research and development of the evacuated tube solar collectors. Garg and Chakravertty [1] developed an empirical relation for finding overall heat loss coefficient in case of evacuated tubular collector for all possible ranges of variables and values compared with the analytically calculated values and found that efficiency decreased in series combination and remained constant for parallel combination. Kumar et al. [2] studied a thermal performance of a community type solar pressure cooker based on evacuated tube solar collector. Morrison et al. [3] developed a number of heat extraction methods from all glass evacuated tubes and found the water in glass concept to be the most successful due its simplicity and low manufacturing cost. Shah and Furbo [4] performed experiments on vertical evacuated tubular collectors. The collector had a tubular absorber and could utilize solar radiation coming from all directions. Results from calculations with the model are compared with measured results and it was found that there occurs a good degree of similarity between the measured and calculated results. And further the thermal performance of the evacuated solar collector was compared to the thermal performance of the flat plate solar collector with an optimum tilt and orientation. Morrison et al. [5] evaluated the characteristics of water-in-glass evacuated tube solar water heaters including assessment of the circulation rate through single-ended tubes. A numerical model of the heat transfer and fluid flow inside a single-ended evacuated tube had been developed assuming no interaction between adjacent tubes in the collector array. Kim and Seo [6] investigated experimentally and numerically the thermal performance of evacuated tube solar collector. Four different shapes of absorber are considered to find the best shape of absorber tube for the solar collector. Shah and Furbo [7] investigated heat transfer and flow structures inside all glass 
evacuated tubular collectors for different operating conditions by means of computational fluid dynamics. The investigations were based on a collector design with horizontal tubes connected to a vertical manifold channel. Generally, the results showed only small variations in the efficiencies. This indicates that the collector design is well working for most operating conditions. Budihardjo and Morrison [8] evaluated the performance of water-in-glass evacuated tube solar collector systems with flat plate solar collectors in a range of locations. The performance of a typical 30-tube evacuated tube array was found to be lower than a typical 2-panel flat plate array for domestic water heating in Sydney. Ma et al. [9] investigated the thermal performance of the individual glass evacuated tube solar collector and analysed the heat loss coefficient, heat efficiency factor by using one-dimensional analytical method and also studied the influence of air layer between the absorber tube and the copper fin on the heat efficiency. The results showed that the function relation of the heat loss coefficient of the glass evacuated tube solar collector with temperature difference between the absorbing coating surface and the ambient air was nonlinear. Yadav and Bajpai [10] investigated experimentally the thermal performance of one-ended evacuated tube solar air collector at different flow rate. Both parallel and counter flows are experimentally examined by changing the position of the blower. It is found that the setup operates more efficiently at a higher flow rate and counter flow. Hayek et al. [11] investigated experimentally the overall performance of solar collectors. Two types of evacuated tube solar collector are used, namely, water-in-glass tube and heat pipe designs. It was found that the heat pipe based collector is better than the water-in-glass tube. And their efficiency is 15 to $20 \%$ higher. Lamnatou et al. [12] presented an evacuated tube collector solar dryer for drying apples, carrots, and apricots experimentally. The mass flow number, along with the maximum collector and fluid exit temperatures, was studied in relation to the minimum entropy generation. Results show that the outlet air temperature was appropriate for drying the agriculture products without preheating of air.

Many researchers have experimentally used the evacuated tube for the heating of water and heating of air with intermediate fluid. The objective of the current experiment is to produce hot air without using any intermediate fluid to produce hot air at different air flow rates and efficiency. The experimental setup is installed at NIT Kurukshetra, India $\left(29^{\circ} 58^{\prime}\right.$ (latitude) North and $76^{\circ} 53^{\prime}$ (longitude) East).

\section{Experimental Setup}

The objective of this experiment is to study the thermal performance of evacuated tube solar air collector and to produce hot air. The photograph of the experimental setup is shown in Figure 1. The setup consists of fifteen glass evacuated tubes, the length and diameter of outer glass tube and absorber tube are $1.5 \mathrm{~m}, 0.047 \mathrm{~m}$, and $0.037 \mathrm{~m}$, respectively. The surface area of evacuated solar air collector is $1.66 \mathrm{~m}^{2}$. The open ends of evacuated tubes are connected to the manifold channel and closed end is supported by frame. Manifold channel is $1.16 \mathrm{~m}$

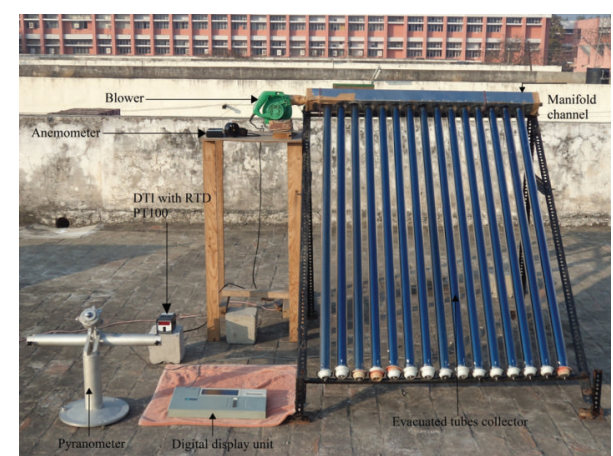

FIGURE 1: Experimental setup of evacuated tube solar air collector.

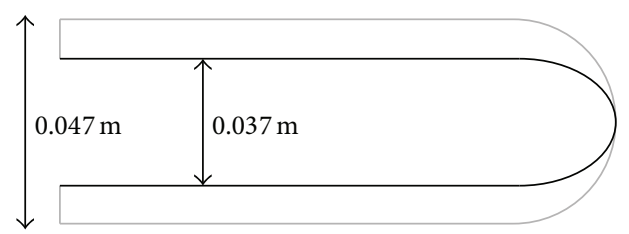

(a)

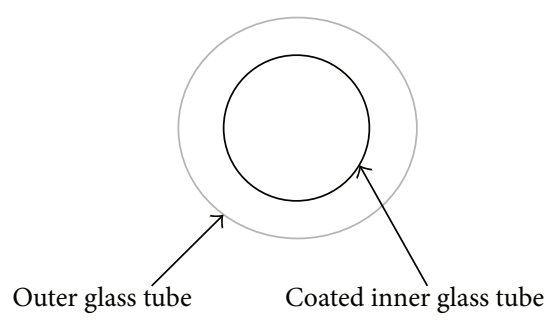

(b)

FIGURE 2: (a) and (b) illustration of glass evacuated tube.

in length and it consists of square pipe at the centre of manifold channel. Blower with regulator is used to blow the air in the evacuated tube and to vary the air flow rate.

The experimental setup consists of the following parts:

(i) evacuated tubes,

(ii) manifold channel,

(iii) reflector.

2.1. Evacuated Tubes. The evacuated tubes used in this system are shown in Figures 2(a) and 2(b). Each evacuated tube consists of two concentric glass tubes which are made from borosilicate glass and between two tubes there is a vacuum. The outer tube is transparent and the inner tube is coated with a coating (Al-N/Al) for better absorption of solar radiation.

2.2. Manifold Channel. The manifold channel used in this system is shown in Figures 3 and 4. It consists of two square pipes one is outer square pipe (stainless steel) and the other is inner square pipe (mild steel). For the surface of outer square pipe, a polyurethane insulation is used to prevent the heat transfer from manifold channel to atmosphere. The inner square pipe is centrally passed through outer square pipe with 


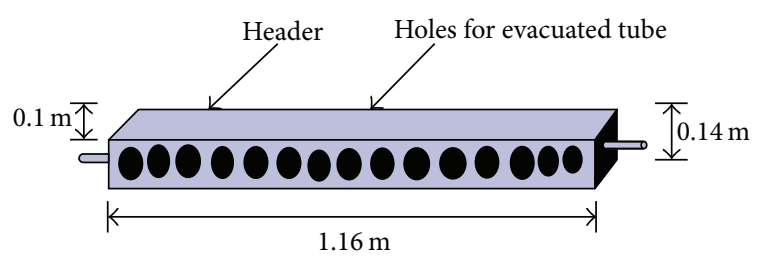

FIGURE 3: Photograph of manifold channel for ETC.

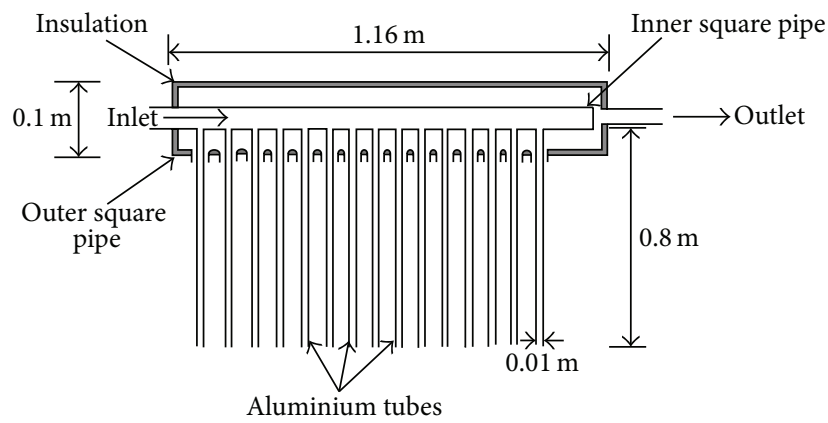

FIGURE 4: Schematic diagram of manifold channel for ETC.

one end closed. The fifteen holes are made on the surface of the outer square pipe in which the open ends of the evacuated tubes are attached and closed ends are supported by the frame. The aluminium tubes are inbuilt with the inner square pipe and are placed inside the evacuated tubes.

2.3. Reflector. Reflector is used under the evacuated tubes to reflect the sunlight onto the evacuated tubes. The size of reflector is $1.55 \times 1.20 \mathrm{~m}^{2}$. It is a GI sheet (galvanised iron) made of mild steel and coated with zinc which has good reflectivity. It can easily reflect the incident solar radiation to the tubes due to which the outlet temperature is increased.

\section{Measuring Device and Instruments}

Different parameters are measured in these experiments:

(i) inlet and outlet air temperatures,

(ii) solar intensity,

(iii) air flow rate.

These parameters are measured by the following devices:

RTD PT100 is used to measure the temperatures at different points. It is connected with a digital temperature indicator that shows the temperature with a resolution of $0.1^{\circ} \mathrm{C}$.

The solar radiation intensity is measured during the day using a Pyranometer (model CM11), supplied by Kipp and Zonen, Holland.

The air flow rate is measured at the beginning of experimental work. A separate probe Anemometer of model AM-4201 is used to measure the velocity of air with an accuracy $\{ \pm(2 \%+1 d)\}$ and resolution $0.1 \mathrm{~m} / \mathrm{s}$.

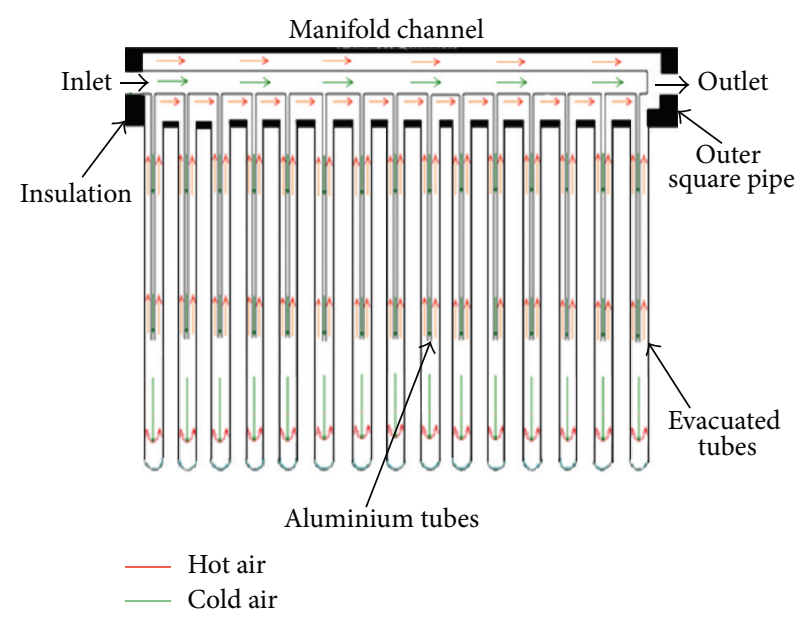

FIgURE 5: Schematic diagram of evacuated tube solar air collector.

The AM-4201 anemometer provides fast and accurate readings, at various velocities, since the vanes are mounted on low friction ball bearings. In addition, it has the convenience of acquiring the data remotely and displaying digitally.

\section{System Operation}

A solar air heating system using one-ended normal evacuated tubes at different flow rates was experimentally investigated. Evacuated tube absorbed solar energy converting it into heat for use in air heating. The schematic diagram of evacuated tube solar air collector is shown in Figure 5. In this operation the inlet air is allowed to pass through the inner square pipe of manifold channel with one end closed. This inlet air flows through the circular directional aluminium tubes into the evacuated tubes where it gains heat due to the solar radiations and heats up, and then it exits from the outer square pipe of the manifold channel. The aluminium tube has diameter $0.01 \mathrm{~m}$ and length $0.8 \mathrm{~m}$. The purpose of the aluminium tube is to separate the hot air from the incoming cold air.

\section{Analysis of Experimental Data}

Thermal performance of the glass evacuated tube solar air collector can be estimated by the solar air collector efficiency which is defined as the ratio of output to the input. Output in this case is the heat gain by air flowing through the manifold channel and input is the energy of the solar radiation falling on evacuated tubes:

$$
\eta=\frac{P_{\text {out }}}{P_{\text {in }}}
$$

where

$$
\begin{gathered}
P_{\text {out }}=\dot{m}_{c} c_{\text {pa }}\left(T_{\text {out }}-T_{\text {in }}\right), \\
P_{\text {in }}=I_{o} A_{p} .
\end{gathered}
$$

Area of the evacuated tube solar collector is given by $\left(A_{p}\right)=$ Number of tubes $\times 2 \mathrm{DL}_{\mathrm{E}}$. 


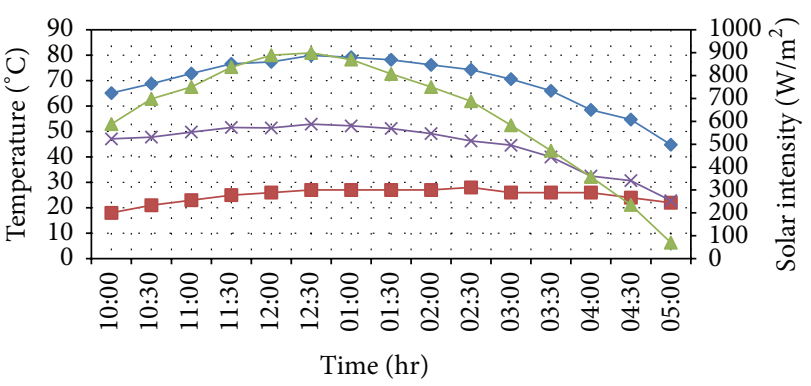

$\longrightarrow$ Outlet air temperature $\quad-$ Inlet air temperature $\left({ }^{\circ} \mathrm{C}\right)$
$\leftarrow$ Temperature difference $\left({ }^{\circ} \mathrm{C}\right) \rightarrow-$ Solar intensity $\left(\mathrm{W} / \mathrm{m}^{2}\right)$

FIGURE 6: Variation of inlet, outlet temperature, temperature difference, and solar intensity at a flow rate of $6.70 \mathrm{~kg} / \mathrm{hr}$.

\section{Experimental Results and Discussion}

In this experimental setup, the main concern is the heating of air at different air flow rate. The experiments were carried out during the month of December 2012, that is, winter-like conditions, at days where the sky was almost clear with some clouds scattered here and there, during which the atmospheric temperature varies from $17^{\circ} \mathrm{C}$ to $26^{\circ} \mathrm{C}$ in most of the days, but reaches up to a maximum value of $28^{\circ} \mathrm{C}$. The experiments were carried out from 10:00 to 5:00.

Four cases have been taken for various results.

(i) Evacuated tube collector without reflector at low air flow rate.

(ii) Evacuated tube collector without reflector at high air flow rate.

(iii) Evacuated tube collector with reflector at low air flow rate.

(iv) Evacuated tube collector with reflector at high air flow rate.

6.1. Case 1: Evacuated Tube Collector without Reflector at Low Flow Rate of $6.70(\mathrm{~kg} / \mathrm{hr})$. At a low air flow rate without reflector, it can be observed that the temperature of outlet air from the evacuated tube solar collector steadily increases. Figure 6 shows the variation of inlet, outlet temperature, temperature difference of air, and solar intensity with time in evacuated tube collector. The maximum solar intensity is $899 \mathrm{~W} / \mathrm{m}^{2}$ at 12:30. The maximum solar intensity is achieved a little during the afternoon, after that it starts decreasing with time. The outlet temperature and temperature difference of air in evacuated tube collector depend upon solar intensity and air flow rate. The temperature of outlet air keeps on increasing at higher rate than the ambient temperature due to high absorption rate of solar radiation in evacuated tubes and minimal reflection properties. The outlet temperature and temperature difference are found to be maximum at noon. When the solar intensity starts decreasing, the inlet, outlet temperature and temperature difference of air also start decreasing. A maximum outlet temperature and temperature difference of air are $79.9^{\circ} \mathrm{C}$ and $52.9^{\circ} \mathrm{C}$ at $12: 30$.

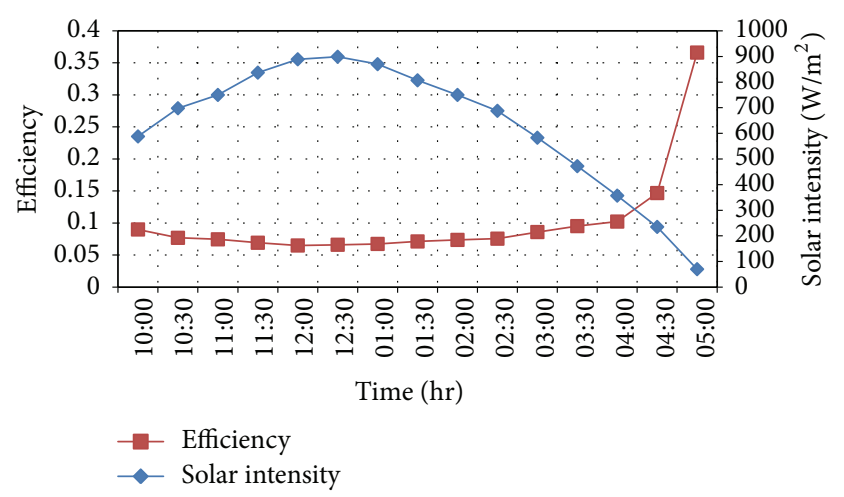

FIGURE 7: Variation of efficiency and solar intensity at a flow rate of $6.70 \mathrm{~kg} / \mathrm{hr}$.

Figure 7 shows the variation of efficiency and solar intensity with time in evacuated tube collector at low air flow rate. The efficiency as shown in Figure 7 is inversely proportional to solar intensity and directly proportional to the temperature difference achieved. Thus, at peak value of solar intensity, the efficiency is near its lowest value. It increases sharply between 04:00 and 05:00 as solar intensity is decreasing. For the rest of the time, the graph is nearly as flat as before noon; the increase in temperature difference is countered by the increase in solar intensity. The maximum efficiency is found to be 0.366 at its lowest solar intensity.

6.2. Case 2: Evacuated Tube Collector without Reflector at High Flow Rate of $13.28(\mathrm{~kg} / \mathrm{hr})$. At a higher air flow rate without reflector, it can be observed that the temperature of outlet air from the evacuated tube solar collector slightly decreases. Figure 8 shows the variation of inlet, outlet temperature, temperature difference of air, and solar intensity with time in evacuated tube collector. The maximum solar intensity is achieved in the afternoon, after that it starts decreasing with time. The maximum solar intensity is $780 \mathrm{~W} / \mathrm{m}^{2}$ at $01: 00$. The outlet temperature and temperature difference of air depend upon solar intensity and air flow rates. The outlet temperature and temperature difference achieved at high flow rate are lower than the case of low air flow rate in evacuated tube solar air collector. This is due to the reduction in residence timing of air for heat transfer inside the evacuated tubes solar air collector. The outlet temperature and temperature difference of air achieved in this case are $69.0^{\circ} \mathrm{C}$ and $42.5^{\circ} \mathrm{C}$ at 01:00.

Figure 9 shows the variation of efficiency and solar intensity with time in evacuated tube collector at high air flow rate. The efficiency as shown in Figure 9 is inversely proportional to solar intensity and directly proportional to the temperature difference achieved. Thus, at peak value of solar intensity, the efficiency is near its lowest value. It increases sharply between 04:00 and 05:00 as solar intensity is decreasing. At high air flow rate the efficiency achieved is higher than the case of low air flow rate in collector because the mass flow rate of air increases very fast, but the change of temperature difference is very small. The maximum efficiency is found to be 0.50 at its lowest solar intensity. 


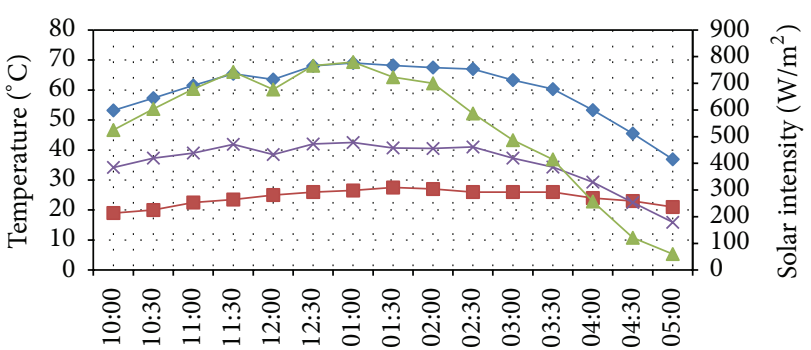

Time (hr)

$$
\begin{aligned}
& \rightarrow \text { Outlet air temperature } \rightarrow-\text { Inlet air temperature }\left({ }^{\circ} \mathrm{C}\right) \\
& \star \text { Temperature difference }\left({ }^{\circ} \mathrm{C}\right) \rightarrow \text { Solar intensity }\left(\mathrm{W} / \mathrm{m}^{2}\right)
\end{aligned}
$$

FIGURE 8: Variation of inlet, outlet temperature, temperature difference, and solar intensity at a flow rate of $13.28 \mathrm{~kg} / \mathrm{hr}$.

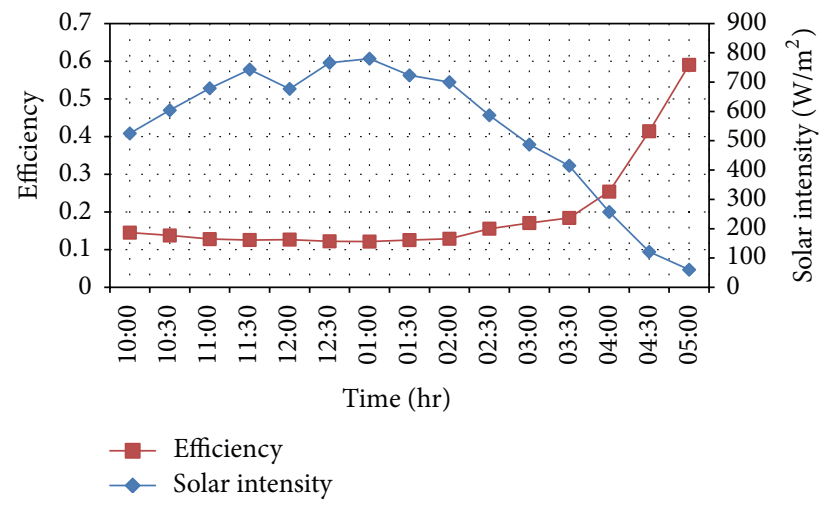

FIGURE 9: Variation of efficiency and solar intensity at a flow rate of $13.28 \mathrm{~kg} / \mathrm{hr}$.

6.3. Case 3: Evacuated Tube Collector with Reflector at Low Flow Rate of $6.70(\mathrm{~kg} / \mathrm{hr})$. At a low air flow rate with reflector, it can be observed that the temperature of outlet air from the evacuated tube solar collector steadily increases because of an increase in the residence time of air at low flow rate. Figure 10 shows the variation of inlet, outlet temperature, temperature difference of air, and solar intensity with time in evacuated tube collector. The maximum solar intensity is $872 \mathrm{~W} / \mathrm{m}^{2}$ at 12:30. The outlet temperature and temperature difference of air in evacuated tube collector depend upon solar intensity and air flow rate. The outlet temperature is found to be maximum at noon. When the solar intensity starts decreasing then outlet, inlet temperature and temperature difference of air also start decreasing. In this case, with reflector, the outlet temperature and temperature difference achieved are higher than that without reflector. A maximum outlet temperature and temperature difference of air are $97.4^{\circ} \mathrm{C}$ and $74.4^{\circ} \mathrm{C}$ is achieved at 12:30.

Figure 11 shows the variation of efficiency and solar intensity with time in evacuated tube collector at low air flow rate with reflector. The efficiency as shown in Figure 11 is inversely proportional to solar intensity and directly proportional to the temperature difference achieved. The efficiency is found to be increasing as the solar intensity decreases after 02:00 due to inverse ratio of temperature difference and intensity at a constant air flow rate. The maximum efficiency is found to be 0.352 at its lowest solar intensity.

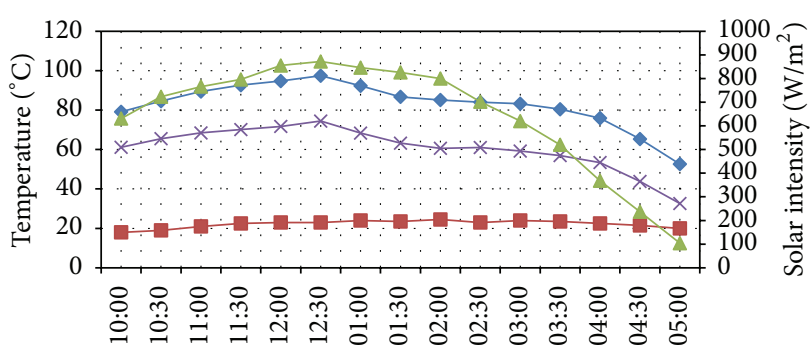

Time (hr)

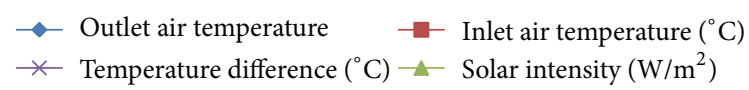

FIGURE 10: Variation of inlet, outlet temperature, temperature difference, and solar intensity at a flow rate of $6.70 \mathrm{~kg} / \mathrm{hr}$.

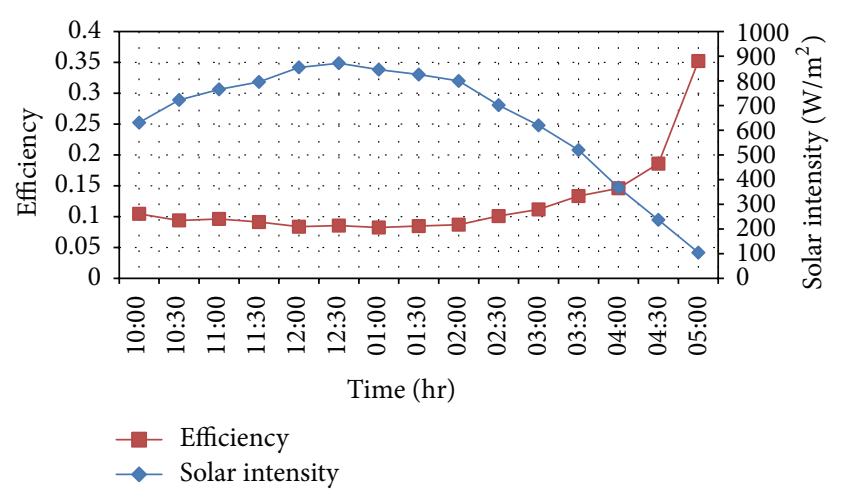

FIGURE 11: Variation of efficiency and solar intensity at a flow rate of $6.70 \mathrm{~kg} / \mathrm{hr}$.

6.4. Case 4: Evacuated Tube Collector with Reflector at High Flow Rate of $13.28(\mathrm{~kg} / \mathrm{hr})$. At a high air flow rate without reflector, it can be observed that the temperature of outlet air from the evacuated tube solar collector slightly decreases. Figure 12 shows the variation of inlet, outlet temperature, temperature difference of air, and solar intensity with time in evacuated tube collector. The maximum solar intensity is achieved in the afternoon, after which it starts decreasing with time. The maximum solar intensity is $818 \mathrm{~W} / \mathrm{m}^{2}$ at $12: 00$. The outlet temperature and temperature difference of air are lower in case of high flow rate than that of low flow rate. This is due to the reduction in residence timing of air for heat transfer inside the evacuated tubes solar air collector. In case of with reflector, the outlet temperature and temperature difference achieved are higher than the case of without reflector. The maximum outlet temperature and temperature difference attained of air are $77.5^{\circ} \mathrm{C}$ and $54.4^{\circ} \mathrm{C}$ at 12:00.

Figure 13 shows the variation of efficiency and solar intensity with time in evacuated tube collector at high air flow rate. The efficiency as shown in Figure 13 is inversely proportional to solar intensity and directly proportional to the temperature difference achieved. It is found that the efficiency of the system at high flow rate is higher than that of low flow rate because the mass flow rate of air increases very fast, but the change of temperature difference is very small. The maximum efficiency in this case is 0.587 . 


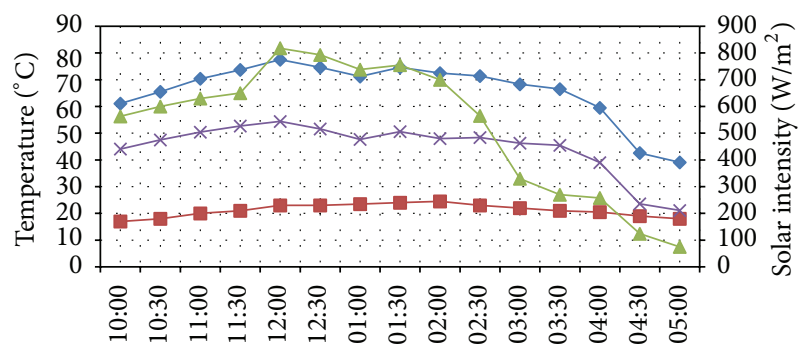

Time (hr)

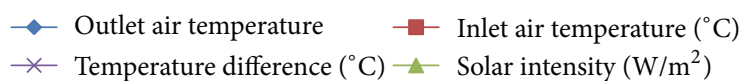

FIGURE 12: Variation of inlet, outlet temperature, temperature difference, and solar intensity at flow rate of $13.28 \mathrm{~kg} / \mathrm{hr}$.

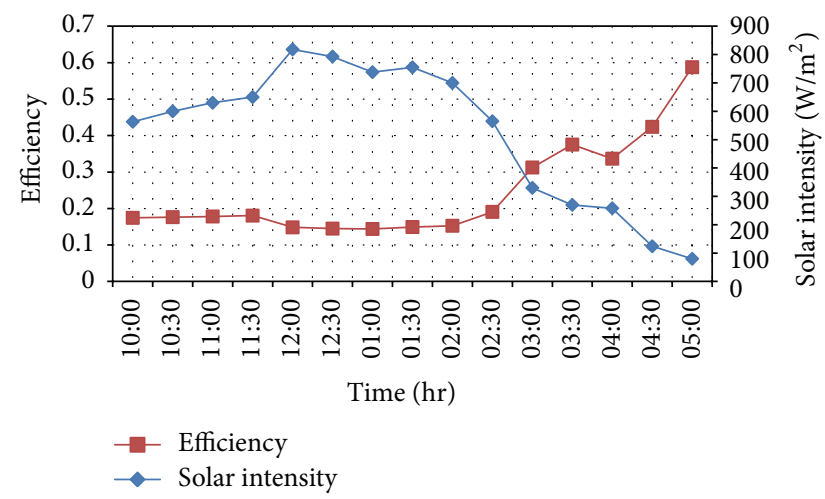

FIGURE 13: Variation of efficiency and solar intensity at a flow rate of $13.28 \mathrm{~kg} / \mathrm{hr}$.

\section{Conclusions}

The following conclusions have been made from the experiments conducted.

(1) The maximum outlet temperature and temperature difference of air achieved at low air flow rate 6.70 $\mathrm{Kg} / \mathrm{hr}$ are $97.4^{\circ} \mathrm{C}$ and $74.4^{\circ} \mathrm{C}$ at $12: 30$ when reflector is employed. The maximum outlet temperature and temperature difference of air achieved at same flow rate are $79.9^{\circ} \mathrm{C}$ and $52.9^{\circ} \mathrm{C}$ at $12: 30$ without the use of reflector, respectively.

(2) The maximum efficiency achieved at high air flow rate $13.28 \mathrm{Kg} / \mathrm{hr}$ is 0.58 at 05:00 when reflector is employed and 0.50 at 12:30 without the use of reflector, respectively.

(3) The maximum temperature difference of air in setup obtained is $74.4^{\circ} \mathrm{C}$ at air flow rate of $6.70 \mathrm{Kg} / \mathrm{hr}$.

(4) It can be concluded that the performance of evacuated tube collector can be significantly be increased with the use of reflector. Further, efficiency, outlet temperature and temperature difference also increase with the use of reflector.

\section{Nomenclature}

ETC: Evacuated tube collector

$T_{\text {out }}$ : Outlet temperature of air, ${ }^{\circ} \mathrm{C}$

$T_{\text {in }}$ : Inlet temperature of air, ${ }^{\circ} \mathrm{C}$

$c_{\mathrm{pa}}$ : Specific heat of air, $\mathrm{J} / \mathrm{kgK}$

$\dot{m}$ : Mass flow rate of air, $\mathrm{kg} / \mathrm{hr}$

$A_{p}:$ Area of evacuated tube solar air collector, $\mathrm{m}^{2}$

$I_{o}: \quad$ Solar radiation intensity, $\mathrm{W} / \mathrm{m}^{2}$

$\eta$ : $\quad$ Evacuated tube solar air collector efficiency.

\section{Conflict of Interests}

The authors declare that they have no financial and personal relationships with other people or organizations that can inappropriately influence their work; there is no professional or other personal interest of any nature or kind in any product, service, and/or company that could be construed as influencing the position presented in the review of the paper.

\section{References}

[1] H. P. Garg and S. Chakravertty, "Thermal analysis of an evacuated tube collector module," Solar and Wind Technology, vol. 5, no. 5, pp. 525-531, 1988.

[2] R. Kumar, R. S. Adhikari, H. P. Garg, and A. Kumar, "Thermal performance of a solar pressure cooker based on evacuated tube solar collector," Applied Thermal Engineering, vol. 21, no. 16, pp. 1699-1706, 2001.

[3] G. L. Morrison, I. Budihardjo, and M. Behnia, "Water-in-glass evacuated tube solar water heaters," Solar Energy, vol. 76, no. 13, pp. 135-140, 2004.

[4] L. J. Shah and S. Furbo, "Vertical evacuated tubular-collectors utilizing solar radiation from all directions," Applied Energy, vol. 78, no. 4, pp. 371-395, 2004.

[5] G. L. Morrison, I. Budihardjo, and M. Behnia, "Measurement and simulation of flow rate in a water-in-glass evacuated tube solar water heater," Solar Energy, vol. 78, no. 2, pp. 257-267, 2005.

[6] Y. Kim and T. Seo, "Thermal performances comparisons of the glass evacuated tube solar collectors with shapes of absorber tube," Renewable Energy, vol. 32, no. 5, pp. 772-795, 2007.

[7] L. J. Shah and S. Furbo, "Theoretical flow investigations of an all glass evacuated tubular collector," Solar Energy, vol. 81, no. 6, pp. 822-828, 2007.

[8] I. Budihardjo and G. L. Morrison, "Performance of water-inglass evacuated tube solar water heaters," Solar Energy, vol. 83, no. 1, pp. 49-56, 2009.

[9] L. Ma, Z. Lu, J. Zhang, and R. Liang, "Thermal performance analysis of the glass evacuated tube solar collector with U-tube," Building and Environment, vol. 45, no. 9, pp. 1959-1967, 2010.

[10] A. Yadav and V. K. Bajpai, "Thermal performance of one-ended evacuated tube solar air collector at different air flow rates: experimental investigation," International Journal of Ambient Energy, vol. 33, pp. 35-50, 2011.

[11] M. Hayek, J. Assaf, and W. Lteif, "Experimental investigation of the performance of evacuated tube solar collectors under eastern Mediterranean climatic conditions," Energy Procedia, vol. 6, pp. 618-626, 2011.

[12] C. Lamnatou, E. Papanicolaou, V. Belessiotis, and N. Kyriakis, "Experimental investigation and thermodynamic performance analysis of a solar dryer using an evacuated-tube air collector," Applied Energy, vol. 94, pp. 232-243, 2012. 


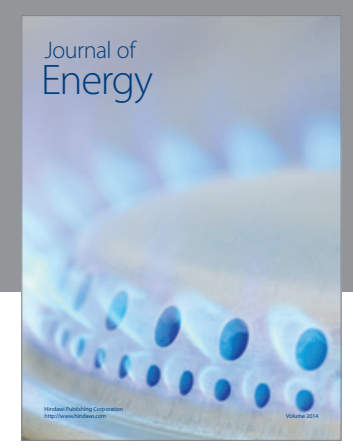

Journal of

Industrial Engineering
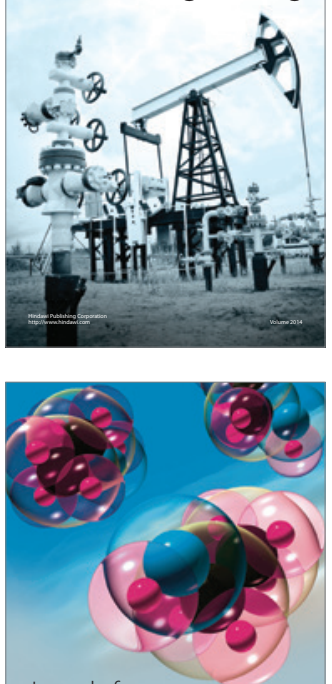

Fuels
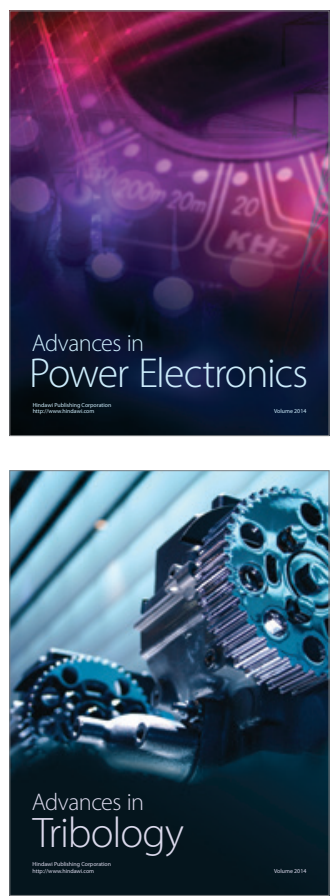

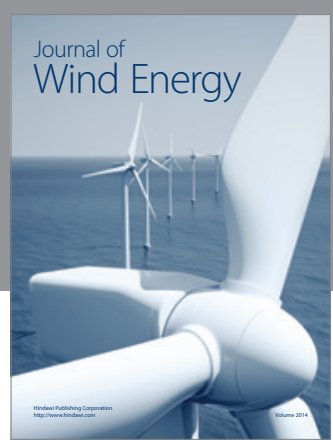

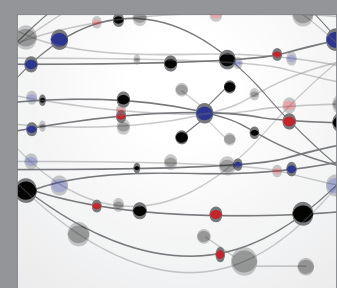

The Scientific World Journal

Submit your manuscripts at http://www.hindawi.com

Journal of

Structures
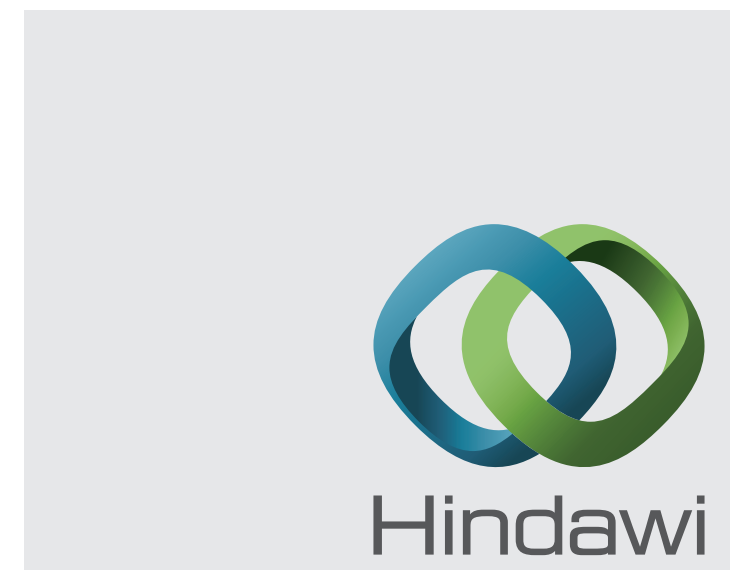

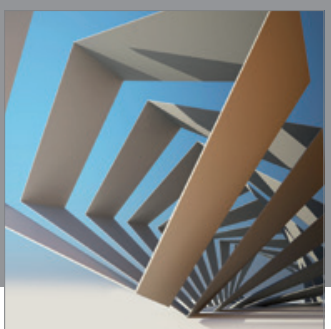

Rotating

Machinery
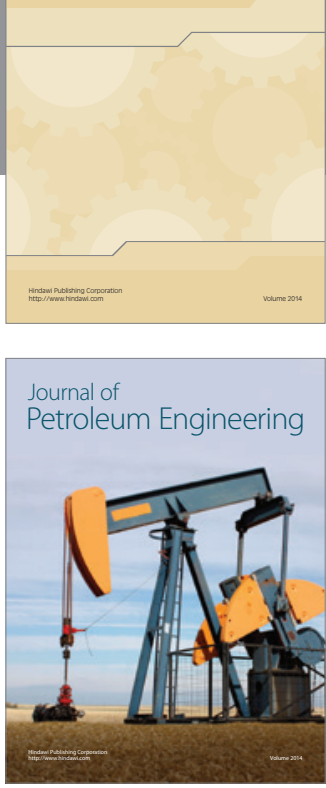

Journal of

Solar Energy
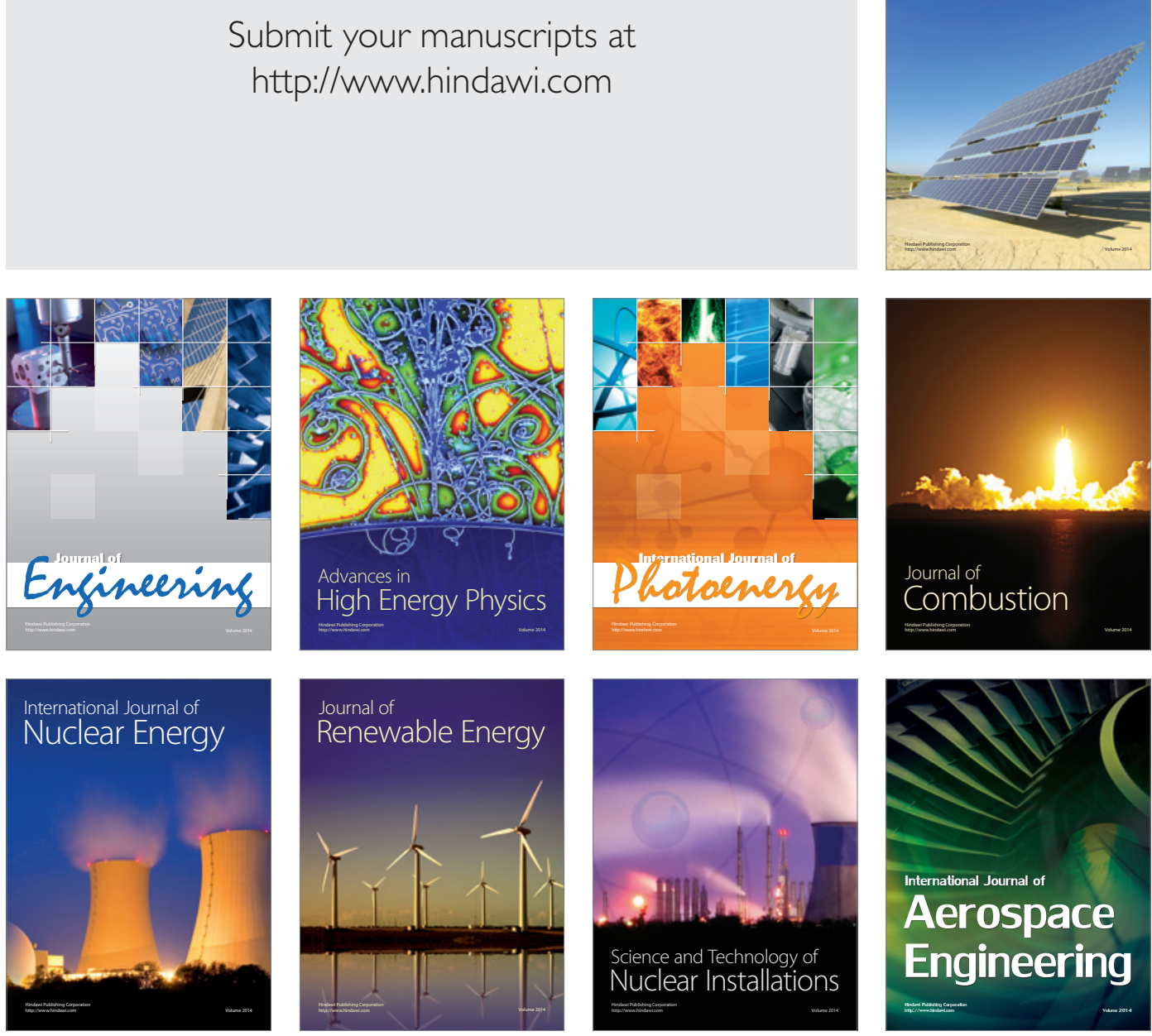